\title{
E-SPORT I PITANJE PRAVNOG USTROJA E-SPORT KLUBOVA
}

\author{
UDK: 796/799 : 004 \\ 795 \\ DOI: $10.31141 /$ zrpfs.2021.58.139.163 \\ Izvorni znanstveni rad \\ Primljeno: 25. listopada 2020.
}

U posljednjih nekoliko godina fenomen elektroničkog sporta (e-sporta ili esporta) dobiva sve veći značaj. Pojam e-sport označava natjecanja koja se održavaju na platformi računalnih ili video igara. Platforma za natjecanje je računalna ili videoigra (program), a ne klasično sportsko borilište. Žanr igara, koje služe kao sportsko borilište, u pravilu uključuje strateške igre u stvarnom vremenu, pucačke igre iz prvog lica i sportske simulacije. Uz svladavanje tehnike računalne igre, igrači za uspjeh u natjecanju moraju imati različite motoričke (koordinacija pokreta, brzina reakcije) i kognitivne sposobnosti (prostorna orijentacija, pregled igre, razumijevanje igre, taktička orijentacija, koncentracija, predviđanje i kreativno razmišljanje). E-sport natjecanja postaju sve privlačnija igračima i klubovima (tzv. klanovima) zbog sve izdašnijih nagradnih fondova. Broj igrača, tzv. gamera u stalnom je porastu. Finala tih natjecanja održavaju se u dvoranama pred tisućama gledatelja. Tu je po svemu riječ o ozbiljnom gospodarskom pothvatu koji diljem svijeta svojim nositeljima donosi znatne prihode. E-sport je na Azijskim sportskim igrama 2017. godine predstavljen sportskoj javnosti koja prati „klasične“ sportove, a Međunarodni olimpijski odbor razmatra mogućnost kako taj oblik natjecanja ustanoviti kao olimpijski sport, te se pomno prati aktivnosti e-sport zajednice. Povodom takvog stava najviših sportskih institucija već se neko vrijeme raspravlja o mogućnosti priznanja e-sporta kao sporta. Posebice se raspravlja o pravnim pretpostavkama koje neko natjecanje i njegovi dionici moraju ispuniti kako bi krovna udruga, koja ih objedinjuje, stekla članstvo u nacionalnom olimpijskom savezu. Nije jednostavno dati jednoznačan odgovor na pitanje je li e-sport uopće sport, jer je tu riječ o ljudskoj natjecateljskoj aktivnosti koja pokazuje mnogo lica: pravno, ekonomsko, antropološko, sociološko. Ovim radom nastoji se dati doprinos razumijevanju pravne strukture e-sporta, uzimajući u obzir i pravnu arhitektoniku e-sporta i njegov regulatorni kontekst, te ukazati na neka pravna pitanja iz motrišta nositelja natjecateljske dimenzije tog kompleksnog gospodarskog pothvata. Razmatraju se razlozi za priznanje e-sporta kao sporta, te se upućuje na pravne učinke tog priznanja. Nadalje, daje se prikaz mogućih rješenja za uređenje pravnog statusa natjecateljskih ekipa u e-sportu. Raspravlja se o mogućnosti ustroja e-sport-klubova u obliku sportskih udruga ili sportskih društava kapitala. Pored toga, upućuje se na rizike, prednosti i nedostatke koje nosi izbor pravnog oblika te se daju preporuke za praksu.

Ključne riječi: e-sport, sportska udruga, sportsko dioničko društvo, Hrvatski olimpijski odbor, organizator 
Izv. prof. dr. sc. Ratko Brnabić: E-sport i pitanje pravnog ustroja e-sport klubova Zbornik radova Pravnog fakulteta u Splitu, god. 58, 1/2021, str. 163-183

\section{UVODNA RAZMATRANJA}

Pojam e-sporta u širem je smislu generički pojam za svako ljudsko natjecanje koje se odvija na platformi računalnih igara različitih žanrova prema unaprijed određenim pravilima. ${ }^{1}$ Nerijetko se spomenute računalne igre dijele u dvije skupine: elektroničke sportske simulacije koje se temelje na nekom od „klasičnih“ sportova kao što su primjerice simulacije nogometa, hokeja, tenisa a (u daljnjem tekstu: e-simulacije $)^{2}$ i ostale računalne igre koje služe kao platforma za natjecanje, iako se uopće ne temelje na nekom od „klasičnih“" sportova (u daljnjem tekstu e-gaming). ${ }^{3}$

Interes za e-sport nezaustavljivo raste, pa privlači sve više igrača (tzv. gamera), gledatelja, trgovaca, ali i medija. Sve su glasniji pozivi da se e-sportu „prizna“ status sporta pa čak i da postane dijelom velike obitelji olimpijskih sportova. Ako bi se prihvatilo polazište da je e-sport ustvari sport, onda bi se na subjekte tog sustava kao lex specialis primjenjivala pravila sportskog prava. ${ }^{4}$

Razvoj e-sporta i prateće industrije prolazi uglavnom neopaženo, što je upravo suprotno ekonomskim pokazateljima koji jasno upućuju na zaključak da je tu riječ o ozbiljnom gospodarskom pothvatu koji ima i svoju sve brojniju klijentelu. E-sport postaje snažno gospodarsko područje koje se svake godine sve više razvija, što pokazuju i dojmljive brojke: e-sportska događanja posjećena su jednako kao i nogometne utakmice, a prijenos uživo na internetu prati milijunski auditorij. ${ }^{5}$ Vrhunski natjecatelji u e-sportu usporedivi su s profesionalcima iz "klasičnih“ sportova: intenzivno treniraju, zahvaljujući sponzorskim prihodima i novčanim nagradama ${ }^{6}$ mogu se baviti samo e-sportom te imaju brojne navijače, jednako kao i popularni sportaši klasičnih sportova.?

Prema najnovijim prognozama, svjetska e-sport industrija ostvarit će u 2020. godini dobit u iznosu 1,1 milijardu dolara u 2020. godini. Predviđa se da će gotovo

1 Brtka, R., ,e-sport: Die Spiele beginnen - Welche Rechtsfragen sind zu klären?“, Gewerblicher Rechtsschutz und Urheberrecht, Praxis im Immaterialgüter und Wettbewerbsrecht (GRUR-Prax), br. 22, 2017., str. 500.

2 Npr. igre FIFA i Pro evolution soccer.

3 Npr. igre League of Legends, Counter Strike, Starcraft itd.

4 Frey, D.; Pommer, J., „Herausforderungen für die weitere Entwicklung des e-sport“, Multimedia und Recht-Beilage (MMR - Beilage), br. 8, 2018., str. 7.

5 U kolovozu 2015. ESL One Cologne zabilježio je 22.000 posjetitelja u Lanxess Areni, dok je 27 milijuna gledatelja utakmice pratilo na mreži. ESL One Frankfurt u lipnju 2015. pratilo je 30.000 posjetitelja u Commerzbank Areni, Intel Extreme Masters u Katowicama, Poljska, u roku od tri dana od 100.000 ljudi. Čak 15.000 ulaznica za finale League of Legends 2015 u Mercedes Benz Areni u Berlinu rasprodano je za manje od 10 minuta, dok je 14 milijuna gledatelja turnir pratilo prijenos uživo putem interneta, a ukupno 36 milijuna gledatelja pogledalo je snimke prijenosa. Računalnu igru „League of Legends" mjesečno igra 70 milijuna igrača širom svijeta. Detaljnije o tome vidi Holzhäuser, F.; Bagger von Grafenstein,T.; Schenk, M., „Ist e-Sport „,echte“ Sport?“, Zeitschrift für Sport und Recht (SpuRt), br. 3., 2016., str. 94 .

6 U 2019. godini 6 najuspješnijih e-sportaša u smislu ostvarenih novčanih nagrada zaradilo je po 3,1 milijuna dolara. Ukupni nagradni fond u 2019. godini iznosio je 215 milijuna dolara.

7 Thorhauer, Y.; Jakob, A.; Ratz, M., „E-Sport - Skizze eines neuen Forschungsfeldes“, u: Thorhauer /Kexel (Ur.), Compliance im Sport - Theorie und Praxis, Springer Gabler, Wiesbaden, 2018., str. 105. i dalje. 
tri četvrtine tog ukupnog iznosa doći od sponzorstva (636,9 milijuna dolara) i medijskih prava (185,4 milijuna dolara). Uz to, prate se i dva nova toka prihoda: digitalni (očekuje se da će u 2020. dobiti iznositi 21,5 milijuna američkih dolara, što je $60,9 \%$ više u odnosu na godinu prije) i streaming (18,2 milijuna, $33 \%$ više). Iako su oba izvora još uvijek mala u usporedbi s najvećim izvorima prihoda kao što su medijska prava i sponzorstvo, njihov brzi rast u odnosu na ostale segmente mogao bi im donijeti napredak u narednim godinama. Očekuje se da će Kina i dalje biti najveće tržište za izvoz s ostvarenim prihodom od 385,1 milijuna dolara u 2020. godini, slijedi Sjeverna Amerika s 252,5 milijuna dolara i zapadna Europa sa 201,2 milijuna dolara. ${ }^{8}$

Za razliku od većine „klasičnih“ sportskih liga, nositelji e-sport pothvata nerijetko imaju višestruku funkciju: istovremeno se pojavljuju kao organizatori natjecanja, nositelji prava iskorištavanja autorskih ali i medijskih prava te kao producenti i pružatelji audiovizualnih i drugih medijskih usluga.

Računalna ili videoigra, koja služi kao platforma za natjecanje, zapravo je software koji se sastoji od računalnog programa (računalni kod) što ga stvaraju programeri, opisa programa i korisničke dokumentacije. Programeri su nerijetko zaposlenici trgovca koji je ujedno i nakladnik (izdavač). ${ }^{9}$ Izdavači se pojavljuju kao organizatori natjecanja i pružatelji medijskih usluga, ali također mogu raspolagati pravom korištenja računalne igre, te naplatno prenijeti to pravo ostalim trgovcima tog sustava - organizatorima priredbi i pružateljima usluga streaming-prijenosa (trgovačka društva - streaming platforme). ${ }^{10}$ Sada je sve veći poticaj za sve izdavače videoigara da svoj novi naslov promoviraju kroz e-sport natjecanja i tako ostvare prednost široke medijske promocije, a s tim u svezi znatno povećaju prihode od prodaje različitih proizvoda u svezi s videoigrom. ${ }^{11}$

Igrači omogućavaju svojim gledateljima praćenje tijeka igre uz komentare i objašnjenja, a često u svojim streaming prijenosima pružaju uslugu reklamiranja. Igrači nakon razmjerno kratke natjecateljske karijere postaju komentatori, analitičari, voditelji natjecateljskih klubova (klanova). Tipični e-sport klub ima

8 Dostupno na https://www.gamesindustry.biz/articles/2020-02-25-newzoo-global-e-sports-marketwill-reach-usd1-1b-in-2020, pregledano 15. IV. 2020.

9 Usp. čl. 9, 56. i 75. našeg Zakona o autorskom pravu i srodnim pravima (Narodne novine 167/2003, 79/2007, 125/2011, 80/2011, 141/2013, 127/2014, 62/2017, 96/2018). Postoji razlika u poimanju autorskog prava što onda utječe i na pravnu prirodu raspolaganja. RH spada u krug država koje autorsko pravo uređuju kao jedinstveno subjektivno pravo (monistički pristup). Države romanskog pravnog kruga kod autorskog prava razdvajaju imovinskopravnu i moralnopravnu komponentu (dualistički pristup), dok se u anglosaksonskim autorskopravnim sustavima copyright poima prvenstveno kao imovinsko pravo a ne kao autorsko pravo. Detaljnije o tome Kunda, I.; Matanovac Vučković R., „Raspolaganje autorskim pravom na računalnom programu - materijalnopravni i kolizijskopravni aspekti“, Zbornik Pravnog fakulteta Sveučilišsta u Rijeci, br. 1, 2010., str. 95-97.

10 Najpopularnije trgovačko društvo - platforma za usluge streaminga je Twitch (https://www. twitch.tv/, pregledano 15. IV. 2020.). Koncern Amazon postao je većinski član tog društva 2014. godine. Thorhauer, Y.; Jakob, A.; Ratz, M., „E-Sport - Skizze eines neuen Forschungsfeldes“, u: Thorhauer / Kexel (Ur.), Compliance im Sport - Theorie und Praxis, Springer Gabler, Wiesbaden, 2018., str. 108.

11 Ponajviše je tu riječ o kupnji ,,virtualnih“ proizvoda tj. raznih dodataka koje igrači kupuju za ostvarenje boljih rezultata u igri (tzv. in-game merchandise). 
više odjela, svaki za drugu igru. Neki poznatiji proizvođači imaju čak i svoje ekipe za natjecanje. Natjecateljske ekipe moraju biti financijski i upravljački samostalne $\mathrm{u}$ odnosu na ostale dionike, a posebice u odnosu na organizatore turnira. Prihode ostvaruju reklamiranjem raznih proizvoda na dresovima, in-stream promotivnim sadržajem, reklamiranjem računalne opreme pojedinih proizvođača i dr. ${ }^{12}$

Organizacijske strukture koje bi odgovarale onima kakve postoje u klasičnim sportovima, još su u ranim fazama razvoja. Udruga International E-sports Federation (u nastavku: IESF) pretendent je na položaj krovne svjetske organizacije, međutim, postoje i drugi e-sport savezi koji bi se mogli uključiti u natjecanje za taj status. ${ }^{13}$ Ta organizacija radi na promicanju e-sporta kao pravog sporta izvan jezičnih, rasnih i kulturnih barijera. Tijekom posljednjih godina postižu značajne uspjehe u organizaciji godišnjeg Svjetskog prvenstva u e-sportu, redovito održavaju skupštinu, a organizacija trenutno ima 56 država članica. Kao međunarodna federacija za e-sport, osim uloge organizatora međunarodnih turnira, IESF stvara autonomna pravila i standarde za međunarodne suce, bavi se pravnom zaštitom igrača i promiče njihov sportski razvoj. Njihov glavni cilj je ostvariti međunarodno priznanje e-sporta kao (olimpijskog) sporta. ${ }^{14}$

U nastavku rada prvo se istražuje postoje li pravne prepreke prihvaćanju e-sporta kao sporta u Republici Hrvatskoj odnosno koje pretpostavke e-sport mora ispuniti da bi bio institucionalno priznat kao sport u RH. Potom se za slučaj takvog priznanja obrađuje pitanje pravnog ustroja e-sport klubova za natjecanje i njihovog udruživanja u savez.

\section{ORGANIZACIJSKI USTROJ "KLASIČNOG" SPORTA I E-SPORTA}

Sport je područje ljudske aktivnosti koje kao područje karakteriziraju zajednički, autonomni sportski ciljeve dionika i potreba njihove suradnje radi postizanja sportskih ciljeva. Dionici sporta povezuju se u saveze, koji su prema svom pravnom obliku najčešće ustanovljeni kao udruge, koje su pak temeljem slobode udruživanja propisane Ustavom. Ustroj i struktura sporta u većini zemalja svijeta nalikuju piramidama,

12 Slično „klasičnim“ sportskim klubovima i natjecateljima koji sklapaju sponzorske ugovore s pojedinim proizvođačima obuće i drugim trgovcima.

13 Tako je primjerice ESL - Electronic Sports League s profesionalnim klubovima osnovao međunarodnu krovnu organizaciju e-sporta pod nazivom World eSports Association (WESA) sa sjedištem u Švicarskoj. Prema ustroju i zadaćama, ta udruga u bitnome slijedi tradiciju tradicionalnih krovnih sportskih saveza. Važni dionici u svijetu e-sporta, izdavačka društva Riot i Valve još se nisu učlanili, ali sudjeluju u razvoju e-sport natjecanja. Ostaje za vidjeti hoće li proizvođači igara koje se koriste za komercijalna e-sport natjecanja poželjeti preuzeti potpunu kontrolu nad tom udrugom. Detaljnije o tome Frey, D.; Pommer, J., „Herausforderungen für die weitere Entwicklung des e-sport“, Multimedia und Recht-Beilage (MMR - Beilage), br. 8, 2018., str. 8.

14 Nedavno su članice tog saveza postale nacionalne krovne e-sport udruge Kolumbije, Kazahstana, Turske i Ukrajine. Dostupno na https://www.sportaccord.sport/exhibition/exhibitors/iesf-international-esports-federation, pregledano 15. IV. 2020. 
zbog čega je ustroj sporta poznat i kao piramidalni model. Pritom, sportski klubovi čine temelj piramide. Oni su članovi svojih lokalnih i/ili regionalnih strukovnih sportskih saveza, koji se zajedno ujedinjuju na nacionalnoj razini u nacionalne sportske saveze. Na regionalnim, nacionalnim te kontinentalnim razinama, a na kraju i na svjetskoj razini, samo je jedan međunarodni sportski savez koji se brine o interesima određene vrste sporta. ${ }^{15}$ Načelo jedne krovne organizacije temeljno je načelo cijelog sustava sporta i dosljedno ga osiguravaju statuti međunarodnih i nacionalnih sportskih udruga. I sudovi također priznaju ovu organizacijsku strukturu sporta kao dopuštenu te se u pravilu ne dovodi u pitanje autonomija sporta. Prednost takvog sustava je u tome što se njime olakšava upravljanje procesima i osigurava jedinstvena primjena pravila, a time se omogućava jedinstveni i jednoobrazni razvoj konkretnog sporta. Utvrđivanje jedinstvenih (autonomnih) pravila u određenoj vrsti sporta pripada ,krovnom” sportskom savezu. ${ }^{16}$

S druge strane, takva struktura dovodi do monopolizacije, a nerijetko takve udruge (točnije savezi udruga) i njihovi dužnosnici stječu veliku moć koja može dovesti do koruptivnog ponašanja. ${ }^{17}$ Kroz strukturu neizravnog članstva, krovne udruge mogu implementirati obvezujuće zahtjeve sve do najniže razine piramide. $\mathrm{Na}$ europskoj razini postoje udruge nacionalnih sportskih udruga, kao što je primjerice za nogomet UEFA. Osim toga, većina svjetskih sportskih udruga zastupljena je u svjetskim sportskim savezima.

Suprotno tome, svijet e-sporta trenutno počiva na drugačijim temeljima. E-sport je izrastao iz supkulture ljubitelja video i računalnih igara i postao samostalan i samoodrživ ekosustav u kojem sudjeluju gospodarski i tržišno moćni igrači. Kod e-sporta ne postoji čvrsta organizacijska struktura koja bi odgovarala ustrojbenoj i hijerarhijskoj strukturi kakva postoji kod klasičnih sportova. Slobode digitalnog svijeta omogućuju e-sportašima da se natječu i bez formiranja piramidalne strukture s krovnim sportskim savezom na čelu. S druge strane, e-sport ekipama (tzv. klanovima) koje su u pravilu pravne osobe, upravljaju profesionalni voditelji poslova (menadžeri) slično kao i kod klasičnih profesionalnih sportskih klubova. Kao organizatori natjecanja pojavljuju se udruge (kao što je primjerice ESL - Electronic Sports League), ali i trgovačka društva koja su proizvođači, odnosno izdavači računalnih igara. I izvan rasprave o priznanju e-sporta organizatori tih natjecanja moraju riješiti niz pravnih pitanja. U smislu autorskog prava postoji razlika prema klasičnim sportovima jer je središnji izazov za organizatore kako stvoriti platformu

15 Čustonja, Z., u: Milanović/Čustonja/Bilić (Ur.), Temeljna načela i smjernice razvoja športa u RH, Nacionalno vijeće za sport, Zagreb, 2011., str. 55., dostupno na https://sdus.gov.hr/UserDocsImages// dokumenti/Nacionalno \%20vije\%C4\%87e\%20za\%20sport//Temeljna\%20na\%C4\%8Dela\%20i\%20 smjernice\%20razvoja\%20sporta\%20u\%20RH.pdf, pregledano 15. IV. 2020.

16 Holzhäuser, F.; Bagger von Grafenstein,T.; Schenk, M., „Ist e-Sport „,echte“ Sport?“, Zeitschrift für Sport und Recht (SpuRt), br. 3, 2016, str. 94.

17 Tako je ove godine odbijena Platinijeva žalba na Europskom sudu za ljudska prava a povodom mjere četverogodišnje zabrane obnašanja funkcija u nogometu zbog primanja mita u iznosu od dva milijuna dolara. Dostupno na https://www.independent.co.uk/sport/football/news-and-comment/michel-platiniarrested-fifa-world-cup-2022-qatar-host-detained-former-uefa-president-a8963146.html, pregledano 15. IV. 2020. 
kojom će se osigurati pošteno i ravnopravno sportsko natjecanje. Organizatori su dužni postaviti opća pravila natjecanja (važni razlozi za isključenje iz natjecanja, broj igrača u jednoj momčadi, transferi igrača, nagradni fond, slučajevi kada postoji više vlasnika), ali pritom moraju osigurati pošteno i ravnopravno nadmetanje što ponekad i nije bio slučaj. Naime, ravnopravnost natjecatelja moguće je primjerice narušiti nedopuštenim softverskim izmjenama, uporabom dopinga, ${ }^{18}$ namještanjem ishoda natjecanja i dr.

Također, uobičajena je praksa proizvođača/izdavača računalnih i videoigara da ih povremeno obnavljaju tj. izdaju nove verzije a one nerijetko sadrže tehničke izmjene. Tu je riječ o postupku ujednačavanja (eng. balancing). Postupkom ujednačavanja tvorci videoigara mijenjaju značajke likova kojima upravljaju igrači. Tako se nekom liku iz videoigre značajke mogu poboljšati (eng. buffing) ili pogoršati (eng. nerfing). ${ }^{19}$ Izdavači (proizvođači) tako temeljem svojih autorskih prava mogu utjecati na ishod natjecanja jer tijekom e-sport sezone mogu umanjiti kvalitativne značajke nekih likova u igri ili igračkih taktika. Stoga se to pitanje mora urediti ugovorom između organizatora i proizvođača kojim će se isključiti pravo izdavača na nova izdanja igre tijekom natjecateljske sezone.

Kada e-sport stekne status ,pravog“ olimpijskog sporta, tada bi videoigra (tj. program, software) koja se koristi kao platforma za natjecanje trebala ostati nepromijenjena u kvalifikacijama i glavnom natjecanju. Uz to, e-sportu je imanentna opasnost zabranjenih postupanja samih igrača, primjerice korištenjem programa kojima se mijenjaju programski parametri igre, te se tako stječe nedopuštena prednost (eng. cheatbots). Takav učinak ima svaki program kojim se može utjecati na ujednačenost igre ili primjerice program kojim se automatiziraju neki procesi što ih inače igrač mora sam provesti.

Izdavači e-sport igara koriste sveobuhvatnu pravnu zaštitu koja se temelji na autorskim i srodnim pravima. ${ }^{20}$ Različito od „klasičnih“ sportova, kod kojih nema zaštite autorskih prava u smislu da je netko osmislio sport i njegova pravila (nije ispunjena pretpostavka „osobnog stvaralaštva“), kod e-sport igara kao softwarea zaštićen je kompjutorski program (programski kod) koji je njihov temelj. Štoviše, predmet pravne zaštite i pojedini su elementi programa (igre) posebice grafike (npr. igrački avatari), scenografija i korisničko sučelje (eng. interface), tekstualni sadržaj (ako je književno djelo) i glazba. Spomenuti elementi, svaki pojedinačno i svi zajedno, predmet su pravne zaštite. Igra se može smatrati i filmskim djelom pa i prema tom kriteriju može biti predmetom pravne zaštite.

18 Npr. propuštanjem organizatora da u dostatnoj mjeri surađuje s institucijama za borbu protiv dopinga.

19 Primjerice ako se liku nogometaša u videoigri (nogometnoj simulaciji) poveća ili umanji maksimalna snaga udarca.

20 Detaljnije o tome Hentsch, H. C., „Die Urheberrechte der Publisher bei e-sport“, Multimedia und Recht-Beilage (MMR - Beilage), br. 8, 2018., str. 3. i dalje. 
Poslovi reklamiranja i sponzorstva također su sastavni element e-sport priredbi jer nerijetko postoje reklamni sadržaji koji su već integrirani u samu igru. ${ }^{21}$ Spor može nastati i onda kada je u videoigru već ugrađena reklama nekog trgovca, a njegov tržišni konkurent bi trebao biti sponzor (pokrovitelj) e-sport natjecanja. ${ }^{22}$

Izdavači igara koriste svoj pregovarački položaj da postave odgovarajuća pravila kako bi se sačuvao integritet natjecanja i promicalo sportsko ponašanje svih sudionika pa najčešće donose i sveobuhvatna pravila za natjecanje slična autonomnim pravilima koja donose npr. nacionalni sportski savezi za neki sport. ${ }^{23}$ Programeri su autori igara, izdavači su ponajprije odgovorni za marketing, odnose s javnošću i prodaju te u bitnome odgovaraju profilu izdavača iz klasičnih medijskih industrija. ${ }^{24}$ Spomenuti trgovci organiziranjem natjecanja populariziraju svoj proizvod pa time povećavaju svoju dobit od prodaje igara i druge robe koja je povezana s računalnom igrom. Uz njih, kao dionici u pothvatu e-sporta pojavljuju se sponzori, ulagači, marketinški sektor, organizatori igara na sreću, gledatelji itd. ${ }^{25}$

Spomenuti sustav stvara dodanu vrijednost za dionike i bez „titule“ sporta pa je pravo pitanje koje bi prednosti i nedostatke imalo priznanje e-sporta za izdavače, organizatore, natjecatelje, klubove (klanove) i ostale dionike. Prednosti koje donosi priznanje e-sporta bile bi njegovo šire društveno prihvaćanje što utječe i na popularnost, bolji pristup javnim izvorima financiranja, lakše ishođenje viza i boravišnih dozvola za e-sportaše, veća pravna sigurnost te brži globalni razvoj temeljem suradnje s drugim sportskim organizacijama. ${ }^{26} \mathrm{~S}$ druge strane, uvjetno rečeno „nedostaci“ su što priznanjem e-sporta ključni dionici e-sportaši i klubovi

21 Taj oblik reklamiranja poznat je pod engleskim nazivom in-game advertising. Primjerice, takav oblik reklamiranja nalazimo u sportskim simulacijama u kojima klubovi imaju jednake dresove kao „pravi“ klubovi, a scenografija odgovara onoj sa stvarnog stadiona tog kluba.

22 Npr. u slučaju kada Coca-Cola sklopi sponzorski ugovor za virtualni panel na virtualnom stadionu u sportskoj simulaciji, a kasnije se pokaže da je glavni sponzor e-sport natjecanja Pepsi. Takve slučajeve treba riješiti unaprijed ugovorom.

23 Primjerice vidi pravilnik za sudjelovanje u natjecanju na platformi igre League of legends, LCS EU - 2018 Season Official Rules, dostupno na https://e-sports-ssets.s3.amazonaws.com/production/files/ rules/ EU_ Rule book. pdf. / (EU LCS), pregledano 15. IV. 2020., koja se osim održavanja natjecanja bavi i problematičnim područjima poznatima iz sportskog prava, npr. pravilo o zabrani ,,višestrukog sudjelovanja“ u klubovima iz istog natjecanja. Detaljnije o tome Jagnow H.; Baumann A., ,e-sport aus verbandlicher Perspektive“, Multimedia und Recht-Beilage (MMR-Beilage), br. 8, 2018., str. 12.

24 Detaljnije o pitanjima sportskog medijskog prava vidi kod Summerer, T., u: Martinek/Semler/Flohr (Ur.), Handbuch des Vertriebsrechts, 4. Auflage, C. H. Beck, München, 2016., § 54. Sportrechtevertrieb, Rn. 21. i dalje.

25 Prirodno je da se proizvođači igara pojavljuju kao organizatori jer žele ostvariti još veću dobit. Tako je poznata izdavačka kuća Riot Games samostalno osnovala natjecateljsku ligu (EU LCS). Europska liga - natjecanje u igri League of Legends (LoL) od 2019. g. postaje predmetom ugovora o franchisinga. Ekipe koji već sudjeluju u natjecanju dužne su platiti članarinu (tzv. buy-in) u iznosu od 8 milijuna eura, a nove ekipe koje žele sudjelovati u natjecanju dužne su uplatiti iznos od 10,5 milijuna eura. Visoki iznosi opravdavaju se činjenicom da nema ispadanja iz lige pa se sudjelovanje u natjecanju može smatrati dugoročnim ulaganjem. U SAD-u izdavačka kuća Activision Blizzard osnovala je ligu Overwatch (skr. OWL) koja planira provesti širenje na europsko tržište. Frey, D.; Pommer, J., „Herausforderungen für die weitere Entwicklung des e-sport“, Multimedia und Recht-Beilage (MMR-Beilage), br. 8, 2018., str. 8.

26 Usp. Bagger von Grafenstein, T., ,e-sport: Welche Vor- und Nachteile bringt eine rechtliche Qualifizierung als Sport mit sich?"“, Herausforderungen für die weitere Entwicklung des e-sport, Multimedia und Recht-Beilage (MMR - Beilage), br. 8, 2018., str. 21. 
Izv. prof. dr. sc. Ratko Brnabić: E-sport i pitanje pravnog ustroja e-sport klubova Zbornik radova Pravnog fakulteta u Splitu, god. 58, 1/2021, str. 163-183

postaju subjekti sportskog prava te se u tom pravnom režimu podvrgavaju propisima o zabrani dopinga, ${ }^{27}$ o zabrani manipulacijama rezultata sportskih natjecanja (prijevara), ${ }^{28}$ o zaštiti maloljetnika, ${ }^{29}$ o igrama na sreću (posebno o sportskom klađenju), ${ }^{30}$ o izuzecima od primjene prava tržišnog natjecanja ${ }^{31}$ itd.

\section{PRETPOSTAVKE ZA PRIZNANJE E-SPORTA KAO SPORTA}

Načelo autonomije pravnog uređenja odnosa u udruzi jamči da svaka udruga slobodno odlučuje hoće li nekoga primiti u svoje članstvo. Stoga je važna značajka autonomnog uređenja odnosa u udruzi upravo okolnost da udruga samostalno određuje pretpostavke koje netko mora ispuniti da bi stekao članski status. Udruga može odbiti nečiji zahtjev za članstvom čak i onda kada podnositelj ispunjava pretpostavke za članstvo.

Spomenuto pravilo ne vrijedi ako je posebnim propisom nekoj udruzi dodijeljen „monopolistički“" status. Kada podnositelj zahtjeva za članstvom u udruzi ispunjava pretpostavke, udruga je tada dužna prihvatiti njegov zahtjev, ako se kumulativno ispunilo da a) savez/udruga kojoj je zahtjev upućen ima monopol, b) postoji važan i opravdan interes podnositelja za stjecanjem članstva i c) odbijanje prijema u članstvo te udruge objektivno bi dovelo do neopravdane uskrate podnositeljevog prava, kojom ga se dovodi u neravnopravan položaj u odnosu na već primljene članove.

Hrvatski olimpijski odbor (u nastavku: HOO) jest udruga s posebnim pravnim položajem i ovlastima, te možemo zaključiti da kao najviša organizacija u sustavu

27 Zakon o sportu, Kazneni zakon (Narodne novine 125/2011, 144/2012, 56/2015, 61/2015, 101/2017, 118/2018, 126/2019), Zakon o sportskoj inspekciji (Narodne novine 86/2012, 98/2019), Zakon o zdravstvenoj zaštiti (Narodne novine 100/2018, 125/2019) itd.

28 Detaljnije o prijevari i povezanim kaznenim djelima kod Pajčić, M; Sokanović, L., „Manipulacija rezultatima sportskih natjecanja“, Zbornik radova Pravnog fakulteta u Splitu, br. 4, 2011., str. 857. i dalje.

29 Npr. vidi Pravilnik o zaštiti maloljetnika u elektroničkim medijima (Narodne novine 28/2015).

30 To bi mogao biti problem za industriju igara jer je uobičajena pojava da je pristup igri besplatan, ali u samoj igri (in-game purchase) moguće je npr. kupiti paket dodataka za bolju izvedbu čiji se sadržaj otkriva tek nakon kupnje pa tu može biti riječi o pojavnom obliku igre na sreću. S druge strane, u Nacionalnom programu razvoja sporta RH od 2019. do 2026. (Narodne novine 69/2019) navodi se da je potrebno razmotriti mogućnost izmjene Zakona o igrama na sreću kako bi se omogućilo povećanje financiranja sporta dodatnim prihodima prikupljenima od klađenja na športske događaje, odnosno potrebno je probati odijeliti prihod od igara na sreću i sportskog klađenja, čime bi se postiglo jasno praćenje oporezivanja klađenja na sport i usmjeravanja tako prikupljenih poreza ka klubovima i nacionalnim sportskim savezima sa svrhom korištenja za rad s djecom (omladinski pogoni), održavanje sportske infrastrukture te pokriće troškova vođenja knjigovodstvenih i revizijskih poslova. Isto tako, potrebno je razmotriti mogućnost dozvole usluge online klađenja stranim priređivačima igara na sreću i reguliranja postotka izdvajanja od istih za sport.

31 Načelno, nacionalnim sportskim savezima pripada pravo autonomnog uređenja njihovih unutarnjih odnosa. Ono proizlazi iz prava na slobodno udruživanje koje je zajamčeno već u ustavima država članica, a uređeno je Poveljom Europske unije o temeljnim pravima koja ima pravnu snagu Ugovora o osnivanju Europske unije. No i autonomija u uređenju unutarnjih odnosa ograničena je prisilnim odredbama kako nacionalnog prava tako i prava Unije. 
sporta ima položaj da odlučuje o prijemu novih članova, a time ta organizacija na neizravan način zapravo odlučuje i o tome što se ima smatrati sportom.

Statutom HOO-a ${ }^{32}$ uređeno je i pitanje stjecanja članstva. Članovi HOO-a nacionalni su sportski savezi, sportske zajednice u županijama i Gradu Zagrebu te druge udruge i ustanove čija je djelatnost od interesa za razvoj hrvatskog sporta i olimpijskog pokreta a odluku o učlanjenju u HOO donosi Skupština HOO-a. Nadalje, članovi HOO-a samostalne su, autonomne udruge s pravnom osobnošću i određenim pravima, obvezama i odgovornostima u HOO-u, koje iskazuju svojim ustrojem, programskom i poslovnom djelatnošću, osiguravanjem financijskih sredstava i drugih uvjeta za svoju djelatnost, pravom odlučivanja iz svog djelokruga. ${ }^{33}$ Punopravni članovi HOO-a mogu biti: nacionalni sportski savez, sportska zajednica u županijama i Gradu Zagrebu ako prihvaćaju Statut HOO-a i ispunjavaju ostale kriterije i uvjete. Tako punopravni član HOO-a može postati nacionalni sportski savez ako je međunarodnu federaciju istog sporta priznao MOO ili da je učlanjena u udruženje međunarodnih sportskih federacija - SportAccord, ${ }^{34}$ da je osnovan sukladno Zakonu o sportu i Zakonu o udrugama i registriran kod nadležnog tijela državne uprave a svrha osnivanja i djelovanja je razvoj i unapređenje, širenje i promicanje sporta u Republici Hrvatskoj prema načelima sporta i olimpizma. Savez mora imati tijela izabrana i registrirana sukladno statutu, Zakonu o sportu i Zakonu o udrugama, te mora donijeti opće akte utvrđene navedenim zakonima i usvojene od nadležnih tijela saveza. Uz to, savez koji pretendira na članstvo u HOO-u trebao bi imati osigurane kadrovske i stručne te osnovne materijalne uvjete za rad i djelovanje. Naposljetku, zbog pravila o jednoj krovnoj organizaciji za svaki sport, drugi nacionalni savez istog sporta ne smije biti već učlanjen u HOO. ${ }^{35}$

Ako skupština HOO-a odluči da je njihovo učlanjenje od interesa za hrvatski sport u cijelosti, pridruženim članom HOO-a može postati nacionalni sportski savez čiju međunarodnu federaciju nije priznao MOO ili čija međunarodna federacija nije učlanjena u udruženje međunarodnih sportskih federacija - SportAccord, te koja nema odgovarajuće kadrovske, stručne i materijalne uvjete za rad. ${ }^{36}$

Skupština HOO-a jest tijelo koje odlučuje o statusu članova pa zapravo odlučuje i o prijemu novih članova. ${ }^{37} \mathrm{~S}$ druge strane Vijeće HOO-a kao njegovo izvršno tijelo predlaže učlanjenje novih članova i utvrđuje pravila postupka za prijem novih

32 Vidi Statut HOO-a od 28. veljače 2018., dostupan na https://www.hoo.hr/hr/dokumenti/4899-hootemeljni-akti, pregledano 15. IV. 2020.

33 Vidi čl. 16. i 17. Statuta HOO-a.

34 Svjetsko udruženje međunarodnih sportskih federacija (Global Association of International Sports Federations - GAISF; prethodno SportAccord) krovna je organizacija za sve (olimpijske i neolimpijske) međunarodne sportske federacije, kao i za organizatore multisportskih igara i međunarodnih udruga povezanih sa sportom. GAISF je međunarodna sportska organizacija sa 95 punopravnih članova (međunarodne sportske federacije koje upravljaju sportovima širom svijeta) i 20 pridruženih članova (organizacije koje provode aktivnosti usko povezane s međunarodnim sportskim savezima).

35 Vidi čl. 17. Statuta HOO-a.

36 Vidi čl. 18. Statuta HOO-a.

37 Vidi čl. 27. Statuta HOO-a. 
članova. ${ }^{38}$ Temeljem te odredbe, Vijeće donosi Pravilnik o kriterijima, uvjetima i postupku za uvrštenje sporta u nomenklaturu sportova i sportskih grana. ${ }^{39}$ Spomenuti Pravilnik izvor je prava kojim se uređuju pretpostavke pod kojima neka ljudska aktivnost stječe status sporta.

Zahtjev za uvrštenje sporta u Nomenklaturu pokreće nacionalni sportski savez, odnosno udruga koja se bavi određenim sportom, odnosno određenom sportskom aktivnošću za koji traži utvrđivanje statusa sporta. Podnositelj zahtjeva dužan je priložiti dokaze o ispunjenju pretpostavki za stjecanje članstva. Stoga bi krovna organizacija za e-sport u RH mogla biti podnositelj zahtjeva za uvrštavanje e-sporta u nomenklaturu. ${ }^{40}$

Da bi neki sport bio uvršten u nomenklaturu sportova, mora ispunjavati najmanje jedan od kriterija: nacionalni sportski savez tog sporta član je pripadajuće međunarodne sportske federacije (dalje u tekstu: MSF) koja je priznata od Međunarodnog olimpijskog odbora (sportovi na programu olimpijskih igara, sportovi na programu zimskih olimpijskih igara, ostali sportovi koji pripadaju MSF-u, priznati od Međunarodnog olimpijskog odbora; sport čiji je nacionalni sportski savez član pripadajućeg MSF-a, priznat od SportAccorda; sport koji je nastao dozvoljenim izdvajanjem (od matičnog nacionalnog sportskog saveza i HOO-a), sukladno pravilima MSF-a, iz sportova navedenih u prvoj alineji ovog članka, čije djelovanje se temelji na razvoju sportskih aktivnosti i sustava natjecanja prema načelima olimpijskog pokreta, a član je pripadajućeg MSF-a, posredno ili neposredno; sport odnosno sportska aktivnost koja se razvija u Republici Hrvatskoj prema načelima Olimpijske povelje i pravilima sporta SportAccorda, sukladno razvoju određenog sporta na međunarodnoj razini, a član je MSF-a čije djelovanje se temelji na razvoju sportskih aktivnosti i sustava natjecanja prema načelima olimpijskog pokreta ili sport, odnosno sportska aktivnost, koja se razvija u Republici Hrvatskoj kao izvorno hrvatski sport s djelovanjem koje se temelji na razvoju sportskih aktivnosti i sustava natjecanja prema načelima olimpijskog pokreta i pravilima sporta SportAccorda, uz ispunjenje ostalih pretpostavki. ${ }^{41}$

Nadalje, sport ili sportska aktivnost mora kumulativno ispunjavati sljedeće uvjete $^{42}$ za stjecanje statusa sporta odnosno za upis u nomenklaturu sportova:

- da je sport odnosno sportska aktivnost za koju se traži priznanje statusa sporta predmet djelovanja podnositelja zahtjeva, s organiziranim i registriranim sportskim djelovanjem najmanje dvije godine u Republici Hrvatskoj,

38 Vidi čl. 56. st. 1. toč. 11. Statuta HOO-a.

39 Vidi Pravilnik o kriterijima, uvjetima i postupku za uvrštenje sporta u nomenklaturu sportova i sportskih grana (u nastavku: Pravilnik o kriterijima) od 23. lipnja 2014., dostupno na https://www.hoo.hr/ downloads/ PRAVILNIK-o-nomenklaturi-2014.pdf, pregledano 15. IV. 2020.

40 Uvid u naš registar udruga pokazuje da je broj e-sport udruga za sada skroman. Pretraga tog registra po ključnim riječima e-sport i e-sport nalazi da u $\mathrm{RH}$ postoji svega 10 takvih udruga, a od njih udruga pod nazivom Hrvatska e-sport federacija barem tim nazivom upućuje na zaključak da je riječ o krovnoj udruzi. Dostupno na https://uprava.gov.hr/registar-udruga/826, pregledano 15. IV. 2020.

41 Vidi čl. 3. Pravilnika o kriterijima.

42 Vidi čl. 5. st. 1. Pravilnika o kriterijima. 
- da je svrha bavljenja sportom odnosno sportskom aktivnošću razvoj i unapređenje, širenje i promicanje sporta u Republici Hrvatskoj prema načelima olimpizma i pravilima sporta SportAccorda,

- da sport odnosno sportska aktivnost ima općim aktom utvrđena pravila o uvjetima i elementima sustava natjecanja u Republici Hrvatskoj te da u razdoblju od najmanje dvije godine provodi organizirani sustav natjecanja $u$ Republici Hrvatskoj uključujući i nacionalno prvenstvo,

- da sportska aktivnost ima osigurane kadrovske i stručne te osnovne materijalne uvjete, odnosno potrebnu sportsku infrastrukturu, koja obuhvaća pitanje sportskog objekta za provođenje aktivnosti, rekvizita za sportske programe kao i financiranje programa, koji su nužni za rad i djelovanje te provođenje programa sporta nije obuhvaćeno drugim sportom u Nomenklaturi kao sportska grana, odnosno programom drugog nacionalnog sportskog saveza koji je nadležan za pripadajući sport u Nomenklaturi sukladno pravilima pripadajuće međunarodne sportske federacije,

- da sport ima registriran nacionalni sportski savez ili udrugu na nacionalnoj razini koja je nadležna za sportsku aktivnost čije se priznanje statusa sporta traži i/ili najmanje tri sportske udruge istog sporta odnosno sportske aktivnosti, $\mathrm{s}$ urednom registracijom pri nadležnim tijelima.

Uz prethodne uvjete traži se da je i sam podnositelj zahtjeva udruga koja ima tijela sukladno Zakonu o udrugama i/ili Zakonu o sportu te je donijela opće akte (statut i pravilnik o sustavu natjecanja), a prihvaća i provodi antidopinška pravila. ${ }^{43}$

Podnositelj uz zahtjev mora priložiti isprave kojima dokazuje da su ispunjeni prethodno nabrojeni uvjeti. Zahtjev upućen HOO-u, odnosno Vijeću prosljeđuje se Radnoj grupi čija je zadaća utvrditi jesu li ispunjeni uvjeti za uvrštenje neke sportske aktivnosti u nomenklaturu sportova. ${ }^{44} \mathrm{U}$ slučaju nedostatnih informacija ili potrebe u svezi sa statusom sporta ili drugih elemenata zahtjeva za uvrštenje u Nomenklaturu, Radna grupa će zatražiti mišljenje MOO-a, odgovarajućeg MSF-a ili drugog međunarodnog ili nacionalnog, vladinog ili nevladinog tijela. ${ }^{45}$

Iz navedenih pretpostavki podnositelj zahtjeva mora vidljivo ispuniti da $\mathrm{HOO}$ i njegova tijela prebacuju dio „tereta procjene“ na međunarodna krovna sportska tijela. Tako je zadaća Radnog tijela Vijeća HOO-a utvrditi je li podnositelj zahtjeva član međunarodne sportske federacije koju priznaje MOO ili barem SportAccord (GAISF). Ako se ta pretpostavka nije ispunila, ostaje mogućnost da je tu riječ o sportskoj aktivnosti koja se razvija u Republici Hrvatskoj prema načelima Olimpijske povelje i pravilima sporta SportAccorda, sukladno razvoju određenog sporta na međunarodnoj razini, a član je MSF-a čije se djelovanje temelji na razvoju sportskih

43 Vidi čl. 5. st. 2. Pravilnika o kriterijima.

44 Vidi čl. 11. Pravilnika o kriterijima.

45 Vidi čl. 12. st. 3. Pravilnika o kriterijima. 
aktivnosti i sustava natjecanja prema načelima olimpijskog pokreta. ${ }^{46}$ Organizacija koja je najbliža pojmu MSF za e-sport mogla bi biti udruga International E-sports Federation (u nastavku: IESF) o kojoj je već bilo riječi u uvodu.

Ostale uvjete za uvrštavanje moguće je ispuniti, uz primjeren angažman zainteresiranih dionika, a prvenstveno podnositelja zahtjeva koji mora stvoriti organizacijsku i pravnu infrastrukturu za ispunjavanje traženih uvjeta. Riječ je o ranije prikazanim, više „tehničkim“ uvjetima ${ }^{47}$ Vidljivo je da se u citiranim pravilima ništa ne govori o tome što neku aktivnost čini sportom. Doduše propisuje se da će radna skupina u slučaju nedostatnih informacija ili potrebe u svezi sa statusom sporta ili drugih elemenata zahtjeva za uvrštenje u Nomenklaturu zatražiti mišljenje MOO-a, odgovarajućeg MSF-a ili drugog međunarodnog ili nacionalnog, vladinog ili nevladinog tijela. ${ }^{48}$

Što u slučaju da Radna skupina našeg HOO-a dobije u rad zahtjev ovlaštenog podnositelja za uvrštavanje e-sporta u Nomenklaturu? Zakon o sportu RH ne sadrži definiciju sporta, niti navodi pretpostavke koje bi neka aktivnost trebala ispunjavati pa da je se na temelju toga smatra sportom. Takvu definiciju ne sadrži statut, a niti ostali autonomni akti Hrvatskog olimpijskog odbora. U Temeljnim načelima i smjernicama razvoja sporta u RH, dokumentu Nacionalnog vijeća za sport to tijelo definira sport u njegovu najširem smislu, a u skladu s definicijom sporta koju je preporučilo Vijeće Europe: „Sport podrazumijeva sve oblike tjelesnoga vježbanja kojima je cilj, neobaveznim ili organiziranim sudjelovanjem, izražavanje ili poboljšavanje tjelesnih sposobnosti i mentalnoga blagostanja, sklapanje društvenih veza ili ostvarivanje rezultata na svim razinama natjecanja". Takvo široko shvaćanje sporta izlazi izvan okvira tradicionalnoga razumijevanja sporta kao natjecateljske aktivnosti kojoj je cilj ostvarivanje sportskoga rezultata. ${ }^{49}$ Prema drugoj definiciji, Sport je skupni pojam za tjelovježbene aktivnosti u kojima dominira natjecateljski duh; njegovanje tjelesnih svojstava i sposobnosti, njihovo provjeravanje i unapređivanje putem igre, borbe i natjecanja, a istovremeno Sport je raširena i popularna društvena pojava te dio kulture suvremenoga društva. ${ }^{50}$ Spomenute definicije su smjernice koje ukazuju na bitne odrednice sporta kakve bi se trebale ispuniti i u e-sportu.

46 Naime s obzirom na okolnost da e-sport nije izvorni hrvatski sport, Predlagatelj se ne može pozivati na čl. 3. alineja 5. Pravilnika o kriterijima: da je riječ o izvorno hrvatskom sportu čije se djelovanje temelji na razvoju sportskih aktivnosti i sustava natjecanja prema načelima olimpijskog pokreta i pravilima sporta SportAccorda.

47 Za početak Hrvatska e-sport federacija, ali i sve e-sport udruge kod nas, u statutima moraju izmijeniti naznačeni cilj i područje djelovanja ako te odredbe uopće ne upućuju na sport i sportsko natjecanje (unijeti u statute vrijednosti navedene u Olimpijskoj povelji). Potom mora donijeti set pravila kojih će se pridržavati svi hrvatski e-sport klubovi. Nadalje Hrvatska e-sport federacija treba zatražiti članstvo u udruzi koja je izgledan kandidat za položaj međunarodne krovne udruge za e-sport (IESF). Uz to potrebno je da se dvije godine provodi organizirani sustav natjecanja.

48 Vidi čl. 12. st. 3. Pravilnika o kriterijima.

49 Milanović/Čustonja/Bilić (Ur.), Temeljna načela $i$ smjernice razvoja športa $u$ RH, Nacionalno vijeće za sport, Zagreb, 2011., str. 10.

50 Leksikonska natuknica uz pojam sport, dostupno na https://www.enciklopedija.hr/Natuknica. aspx?ID=59859, pregledano 12. IV. 2020. 
Usporedbe radi, u nastavku se daje prikaz Pravilnika o prijemu članova Njemačkog olimpijskog saveza (Deutscher Olympischer Sportbund, u nastavku: DOSB $)^{51}$ kod kojega je sasvim drugačiji pristup prilikom prijema novih članova. Naime, uz organizacijske pretpostavke za prijem u članstvo, Pravilnikom su uređene i tzv. ,sportske“" pretpostavke, a to su zapravo značajke prema kojima procjenjujemo koje od mnogobrojnih ljudskih aktivnosti možemo svrstati pod pojam sporta.

DOSB načelno uređuje pitanje zahtjeva za prijem novih članova odredbom čl. 7. st. 2. statuta DOSB-a, ${ }^{52}$ ali se ta problematika razrađuje detaljno Pravilnikom o prijemu članova.

Službeno, DOSB nije forum koji daje obvezujuću definiciju pojma sporta, niti je ovlašten za njezino izvorno tumačenje, međutim, s obzirom na to da je riječ o krovnoj organizaciji njemačkog sporta koja broji više od 27,7 milijuna (neizravnih) članova, DOSB ima velik utjecaj na definiranje pojma sporta. Prema tom Pravilniku, da bi e-sport bio prihvaćen kao sport, posebice olimpijski sport, moraju se ispuniti sljedeće pretpostavke:

1) Prakticiranje tog sporta mora za cilj imati natjecateljevu motoričku aktivnost koja je potrebna za sudjelovanje/natjecanje. Vlastita motorička aktivnost je izostala ili je minimalna kod misaonih igara, modelarstva, treniranje životinja ali bez kretanja osoba kao i kod upravljanja uređajima a bez kretanja osobe koja njime upravlja;

2) Natjecateljeva motorička aktivnost mora predstavljati sportski cilj. ${ }^{53} \mathrm{Ta}$ se pretpostavka nije ispunila kod kretanja radi obavljanja rada ili svakodnevnih aktivnosti;

3) Sport i sustav njegovih natjecateljskih pravila moraju osigurati zaštitu etičkih vrijednosti kao što su načelo fair playa i ravnopravnosti natjecatelja te zaštitu natjecatelja od ozljeđivanja. Ta se pretpostavka nije ispunila ako je isključiva svrha te aktivnosti ostvarivanje dobiti, odnosno ako ta aktivnost uključuje stvarno ili simulirano nanošenje ozljeda suparničkim natjecateljima.

Odlučujuća pretpostavka za priznanje e-sporta kao sporta jest prema DOSB-u motorička aktivnost koja određuje vrstu sporta. Prema općem mišljenju, to se kao dio sportskog koncepta nikako ne može izjednačavati s razvojem fizičke snage u smislu klasičnih sportova. Umjesto toga, upotreba tjelesnih vještina je presudna,

${ }^{51}$ Pravilnik za prijem članova Njemačkog olimpijskog saveza (DOSB Aufnahmeordnung), dostupno na https://cdn.dosb.de/user_upload/www.dosb.de/uber_uns/Satzungen_und_Ordnungen/aktuell_ Aufnahmeordnung_2018_pdf, pregledano 15. IV. 2020.

52 Statut Njemačkog olimpijskog saveza dostupan na https://cdn.dosb.de/user_upload/www.dosb. de /uber_uns/Satzungen_und_Ordnungen/aktuelle_Satzung_2019_Dez._2019_pdf, pregledano 15. III. 2020.

53 E-sport odvojen je od razmatranja (shvaćanja) pojma „korisnosti“ koji vrijedi u svakodnevnom životu i radu, a to prvenstveno zbog toga što je, kao i kod klasičnih sportova (tenisa, nogometa), riječ o igranju, igri koja se odvija u obliku simbolizacije stvarnosti, usmjerenoj na ostvarenje autonomnog sportskog cilja. Thorhauer, Y.; Jakob, A.; Ratz, M., „E-Sport - Skizze eines neuen Forschungsfeldes“, u: Thorhauer /Kexel (Ur.), Compliance im Sport - Theorie und Praxis, Springer Gabler, Wiesbaden, 2018., str. 112. 
Izv. prof. dr. sc. Ratko Brnabić: E-sport i pitanje pravnog ustroja e-sport klubova Zbornik radova Pravnog fakulteta u Splitu, god. 58, 1/2021, str. 163-183

kao što su, osim razvijanja snage, brzina, izdržljivost, vještina i koordinacija, pa je DOSB priznao status sporta npr. i pikadu, u kojem za uspjeh u natjecanju fizička snaga i kondicija imaju zanemariv značaj. ${ }^{54}$

E-sport je aktivnost za koju je potrebna visoka razina spretnosti i koordinacije što zahtijeva razmjerno visoku razinu tjelesnih napora. Profesionalni e-sportaši kliknu mišem, tipkovnicom ili drugim upravljačkim uređajem do 400 puta u minuti, a tijekom natjecanja moraju dulje vrijeme zadržati koncentraciju i biti sposobni pravovremeno reagirati, te uz to $i$ ispunjavati taktičke zamisli. Nadalje, zbog sve većeg stupnja realnosti računalnih igara, igrači su izloženi stresu. ${ }^{55} \mathrm{Za}$ ispunjenje tih zahtjeva potrebna je i primjerena tjelesna sprema. ${ }^{56}$

Iz svega proizlazi da se e-sport razlikuje od igara koje su isključivo misaonog značaja, a temeljem podataka o motoričkim sposobnostima i kondiciji što je posjeduju e-sport natjecatelji koji se natječu na najvišoj razini, nije posve neutemeljen stav prema kojem e-sport ispunjava zahtjev da je tu riječ o motoričkoj aktivnosti (prvi zahtjev) čija je svrha ostvarenje sportskih (natjecateljskih) ciljeva (drugi zahtjev). Preostali (treći) zahtjev jest da sustav pravila e-sporta mora biti utemeljen na etičkim vrijednostima $^{57}$ uz zabranu nanošenja ozljeda (stvarnih ili virtualnih) suparničkim natjecateljima. U najmanju ruku simulacije sportova, pa i borilačkih, mogu ispuniti te zahtjeve jednako kao što ih ispunjavaju borilački kontakt-sportovi.

54 U raspravama o priznanju e-sporta njegovi zagovornici opetovano navode primjer šaha igre koja ima poseban status u njemačkom sustavu sporta. DOSB u dokumentu iz 2006 g. navodi da igrač turnirske inačice šahovskog natjecanja mora ispunjavati visoke kognitivne ali i fizičke zahtjeve. Znanstvena istraživanja pokazuju da se stres uzrokovan igranjem šaha može lakše prevladati ako je igrač-natjecatelj u primjerenoj fizičkoj kondiciji. Temeljem toga DOSB 2006. godine zaključuje da se turnirski šah ima smatrati sportom. Detaljnije o tome DOSB, Die Frage vom 8. V. 2006: Warum gilt Schach eigentlich als Sportart?, članak dostupan na http://www.dosb.de/de/service/frage-derwoche/detail/news/die_frage_ vom_08052006/, pregledano 15. IV. 2020.

Uvođenjem u Pravilnik za prijem članova DOSB-a pretpostavke da mora biti riječi o samostalnoj vlastitoj motoričkoj aktivnosti sportaša (2013.), šah je u SR Njemačkoj izgubio status olimpijskog sporta. Schneider, Ilja. „Ist Schach ein Sport?“, Zeit online (2014.), dostupno na http://blog.zeit.de/schach/istschach-ein-sport/., pregledano 12. IV. 2020.

55 Razina kortizola profesionalnih igrača za vrijeme natjecanja približno je na razini igrača klasičnih sportova tijekom utakmica/natjecanja. Nalazi znanstvenog istraživanja pokazali su da se koncentracija kortizola značajno povećala nakon igranja igara „Strah“, „Trkač“ i „Uzbuđenje“, a znatno se smanjila nakon igranja igre Puzzle. Vidi kod Aliyari H. et al., „The Beneficial or Harmful Effects of Computer Game Stress on Cognitive Functions of Players“, Basic Clinical Neuroscience, 9(3), 2018., str. 177. dalje, dostupno na https://www.ncbi.nlm.nih.gov/ pmc/articles/PMC6037427/, pregledano 15. IV. 2020.

56 Tako profesionalni e-sportaši - osim treninga stvarnih igara - ne mogu proći bez gotovo svakodnevnog treninga snage. Leđni mišići moraju posebno omogućiti igraču da sjedi bez napetosti tijekom meča i da optimalno koristi upravljačke uređaje tj. igračko sučelje.

57 O posebnim opasnostima za integritet e-sporta vidi detaljnije kod Kubiciel, M., „Entwicklung des e-sports und Schutz seiner Integrität“, Zeitschrift für Rechtspolitik, br. 7, ZRP, 2019., str. 200. i dalje. Kod e-sporta moguće su prijevare, primjerice korištenjem posebnih programa tzv. botova, prisutan je $i$ problem dopinga, a zamislive su i kladioničarske prijevare (pranje novca, sumnjive uplate). Osiguranje poštenog sportskog natjecanja bit će ključno za daljnju popularizaciju e-sporta. Usp. Bagger von Grafenstein, T., ,e-sport: Welche Vor- und Nachteile bringt eine rechtliche Qualifizierung als Sport mit sich?", Herausforderungen für die weitere Entwicklung des e-sport, Multimedia und Recht-Beilage (MMR -Beilage), br. 8, 2018., str. 22. 
Odlučujuću riječ o „sportskoj“ sudbini e-sporta imat će ponajprije Međunarodni olimpijski odbor (u nastavku: MOO). Vrijedi spomenuti da je MOO među prvima zapravo i ohrabrio e-sport zajednicu, jer se u zaključcima sa 6. Olimpijskog kongresa $^{58}$ navodi da e-sport pokazuje značajan rast, posebno u demografskim kategorijama mladih u brojnim zemljama, te da e-sport može biti dio olimpijskog pokreta. Natjecateljski e-sport može se smatrati sportskom aktivnošću, ali da bi bio priznat kao sport, njegov sadržaj mora biti u skladu s vrijednostima olimpizma. Nadalje, dionici e-sporta dužni su stvoriti organizacijsku piramidalnu strukturu s krovnom organizacijom čija je zadaća osigurati provedbu pravila MOO-a (posebice onih o dopingu i sportskom klađenju). Kongres je dao preporuku MOO-u i Svjetskom udruženju međunarodnih sportskih federacija (GAISF-u) da dublje istraže to područje te da započnu dijalog s predstavnicima industrije računalnih i videoigara i ostalim ključnim dionicima e-sporta. Međutim, u zaključcima s 8. olimpijskog kongresa zauzima se stav o „pristupu u dvije brzine“. Kongres u svezi sa sportskim simulacijama vidi veliki prostor za suradnju i njihovo uključivanje u sportski pokret. Mnoge sportske simulacije postaju sve bliže „klasičnom“ sportu zahvaljujući razvoju virtualne i proširene stvarnosti. Međunarodne federacije za svaki sport trebaju ispitati kako upravljati elektroničkim i virtualnim oblicima tog sporta, te u suradnji s izdavačima igara istražiti razvojne mogućnosti. U svezi s ostalim elektroničkim igrama (igrama koje nisu sportske simulacije), Kongres zaključuje da se u ovoj fazi sportski pokret treba usmjeriti na igrače a ne na određene igre. Usmjerenost na pojedinca trebala bi služiti promicanju sudjelovanja u sportu i zdravog načina života, ali i promicanju brige o mentalnom zdravlju. Ističe se važnost kontinuiranog dijaloga između olimpijskog pokreta i e-sport zajednice s ciljem razvijanja strateških partnerstava, a potrebno je razviti i smjernice za održive odnose između dionika iz sustava „klasičnih“ sportova i e-sport zajednice. ${ }^{59}$

\section{PRAVNI OBLICI E-SPORT NATJECATELJSKIH KLUBOVA}

Rasprava o pravnom obliku e-sport klubova koji sudjeluju u natjecanjima dobit će na značaju posebice kada (prije nego ako) e-sport dobije status sporta. U tom slučaju će se u RH na dionike e-sporta primjenjivati Zakon o sportu. ${ }^{60} \mathrm{Bez}$ obzira na to je li tu riječ o rekreativnoj ili natjecateljskoj inačici e-sporta, u statusnom smislu subjekti natjecanja mogu biti sportaši fizičke osobe, a kada je riječ o natjecanju u kojem sudjeluju klubovi, tada jednako kao i kod „klasičnog“ sporta oni mogu biti ustrojeni kao sportske udruge ili sportska dionička društva. Sve više sportskih klubova svom natjecateljskom pothvatu pridodaje i e-sport-odjele ili se

58 Komunikacija od 28. X. 2017, dostupno na https://www.olympic.org/news/communique-of-theolympic-summit, pregledano 15. IV. 2020.

59 Deklaracija 8. olimpijskog kongresa od 7. XII. 2019., dostupno na https://www.olympic.org/news/ declaration-of-the-8th-olympic-summit, pregledano 15. IV. 2020.

60 Zakon o sportu (Narodne novine 71/2006, 150/2008, 124/2010, 124/2011, 86/2012, 94/2013, 85/2015, 19/2016, 98/2019, 47/2020). 
u svrhu sudjelovanja u natjecanju osnivaju novi e-sport klubovi. ${ }^{61}$ Udruga je trajno organizirano, privatnopravno povezivanje osoba koje slijede zajednički cilj, a nastaje pravnim poslom. ${ }^{62}$ Udruga je i svaki oblik slobodnog i dobrovoljnog udruživanja više fizičkih, odnosno pravnih osoba koje se, radi zaštite njihovih probitaka ili zauzimanja za zaštitu ljudskih prava i sloboda, zaštitu okoliša i prirode i održivi razvoj, te za humanitarna, socijalna, kulturna, odgojno-obrazovna, znanstvena, sportska, zdravstvena, tehnička, informacijska, strukovna ili druga uvjerenja i ciljeve koji nisu u suprotnosti s Ustavom i zakonom, a bez namjere stjecanja dobiti ili drugih gospodarski procjenjivih koristi - podvrgavaju pravilima koja uređuju ustroj i djelovanje toga oblika udruživanja (skupno, zajedničko djelovanje na područjima od zajedničkog interesa čime se ujedno promiču opće prihvaćene vrijednosti nekog društva, države). ${ }^{63}$

Članovi upravljaju udrugom neposredno ili putem izabranih predstavnika u tijelima udruge, pri čemu je statut jedini akt udruge u kojem se smiju nalaziti odredbe o upravljanju udrugom. Zakon o udrugama ne uređuje upravljanje udrugom već je to prepušteno autonomnom uređenju, uvjet je samo da udruga ima skupštinu i barem jednu fizičku osobu ovlaštenu da je zastupa. Najčešće udruge, uz skupštinu, imaju upravni i nadzorni odbor pri čemu je spomenuta fizička osoba ovlaštena na zastupanje, najčešće predsjednik upravnog odbora udruge (u nastavku teksta: predsjednik udruge).

Predsjednik udruge vodi poslove udruge na vlastitu odgovornost, a sve poslove koji su mu povjereni mora osobno izvršavati i ne smije ih prenijeti na treće. ${ }^{64}$ Predsjednik udruge dužan je, za razliku od uprave dioničkoga društva, postupati po uputama skupštine. ${ }^{65}$ Skupština članova udruge najvažniji je organ udruge i ona smije davati upute o svim aktivnostima udruge, osim ako to pitanje statutom nije drugačije uređeno. ${ }^{66}$

Nema prepreke da udruga osnuje neko od trgovačkih društava, koja su po naravi stvari usmjerena na stjecanje dobiti. Bitno je da su djelatnosti koje donose dobit drugorazrednog značaja u odnosu na primarni, idealni (neprofitni) cilj udruge. Drugačiji je slučaj kad udruga sudjeluje u podjeli (isplati) dobiti u trgovačkom društvu koju zatim proslijedi (isplati dalje) svojim članovima ili trećima. Stoga se tvorevina koja isplaćuje dobit svojim članovima ne smije registrirati kao udruga već mora poslovati u pravnom obliku nekog od društva kapitala, jer propisi koji uređuju ta društva sadrže odredbe o održanju kapitala, a posebice one o zabrani isplate sredstava iz imovine tih društava. Međutim, dopustivo je da udruga ostvarenu dobit

${ }^{61}$ Bagger von Grafenstein,T.; Bischoff, D., „Schaffung von e-Sport-strukturen in Verein“, Zeitschrift für Sport und Recht (SpuRt), br. 2., 2020., str. 77.

${ }_{62}$ Schmidt, K., „Gesellschaftsrecht“, 4. Auflage, Köln - Berlin - Bonn - München, 2002., str. 659.

63 Zakon o udrugama (Narodne novine 74/2014, 70/2017, 98/2019).

64 Stöber, K., „Handbuch zum Vereinsrecht“, 8. Auflage, Köln, 2000., str. 180.

65 Ibid.

66 Schmidt, K., „Gesellschaftsrecht“, str. 691. 
zadrži (tezaurira) te ponovno ulaže što je primjerice slučaj kod nogometnih klubova koji su registrirani kao udruge. ${ }^{67}$

Ako se osniva e-sport udruga tada nema mjesta, a niti potrebe za njezinu integraciju u strukturu nekog sportskog kluba. Statut udruge i njezina temeljna struktura mogu se fleksibilno oblikovati, uz pridržavanje odredbe o bitnim sastojcima tog akta. ${ }^{68}$ Moguće rješenje jest i da se u sportskom klubu osnuje odjel za e-sport.

E-sport klubovi mogu biti ustrojeni u pravnom obliku sportskih dioničkih društava. Osnivanjem e-sport dioničkog društva nastao je pravni subjekt kojem je fokus djelovanja sudjelovanje na e-sport natjecanjima a ustroj i autonomne akte može prilagoditi tom cilju. Gospodarski značaj dioničkog društva jest u tome što taj pravni oblik može prikupiti znatna sredstva od velikog broja ulagača i djelovati kao kapitalni fond. ${ }^{69} \mathrm{Uz}$ to, dioničko društvo može se financirati izdavanjem dionica putem burzi, za razliku od ostalih trgovačkih društava našeg prava koja razvijaju drugačiji pristup prema ulagačima. ${ }^{70} \mathrm{U}$ tim društvima može biti više članova (dioničara), a pravna osoba može primjerice sklopiti sponzorski ugovor s odredbom o isključivim pravima. Riječ je o osnivanju trgovačkog društva što ništa ne mijenja postupak s obzirom na to da je riječ o e-sport pothvatu. U odnosu na sportske udruge, propisi o udrugama ne daju upravi udruge, odnosno predsjedniku (kod nas) ovlasti kakve ima uprava dioničkog društva. ${ }^{71} \mathrm{U}$ interesu profesionalnog vođenja poslova i zastupanja društva to nije zadaća dioničara već uprave društva koja to čini na vlastitu odgovornost. Uprava dioničkog društva sastoji se od stručnjaka koji nisu nužno i članovi društva kapitala - dioničari. Stoga pravni oblik dioničkog društva predstavlja primjeren ustrojbeni oblik kojim će se ostvariti profesionalizacija upravljanja društvom. Kao što je ranije istaknuto, uprava vodi poslove društva na vlastitu odgovornost i nije vezana uputama glavne skupštine. Profesionalno-etička, materijalno-pravna i statusno-pravna odgovornost predsjednika i članova uprave

${ }^{67}$ U njemačkoj literaturi ističe se da je riječ o gospodarskoj udruzi ako je to posljedica njezinoga pravnog statusa. Primjerice, ako je udruga član javnog trgovačkog društva ili komplementar u komanditnom društvu, pripisuje joj se položaj poduzetnika tj. trgovca. Smatra se da, zbog zaštite pravnih poslova, nije dopustivo da udruga koja stupa u taj položaj ima drugačiji status od ostalih članova koji su trgovci (poduzetnici). Kada bi to bilo drugačije, ne bi postojalo samo društvo GmbH \& Co. KG, nego i društvo e.V. \& Co. KG (komanditno društvo u kojem je udruga komplementar). Schmidt, K., Verbandszweck und Rechtsfähigkeit im Vereinsrecht, Eine Studie über Erwerb und Verlust der Rechtsfähigkeit nichtwirtschaftlicher und wirtschaftlicher Vereine, Heidelberg, Decker, 1984., str. 125.

68 Prema čl. 13. Zakona o udrugama Statut udruge sadrži odredbe o: nazivu i sjedištu, zastupanju, područjima djelovanja sukladno ciljevima, ciljevima, djelatnostima kojima se ostvaruju ciljevi, gospodarskim djelatnostima sukladno zakonu, ako ih obavlja, načinu osiguranja javnosti djelovanja udruge, uvjetima i načinu učlanjivanja i prestanku članstva, pravima, obvezama i odgovornosti te stegovnoj odgovornosti članova i načinu vođenja popisa članova, tijelima udruge, njihovu sastavu i načinu sazivanja sjednica, izboru, opozivu, ovlastima, načinu odlučivanja i trajanju mandata te načinu sazivanja skupštine u slučaju isteka mandata, izboru i opozivu likvidatora udruge, prestanku postojanja udruge, imovini, načinu stjecanja i raspolaganja imovinom, postupku s imovinom u slučaju prestanka udruge, načinu rješavanja sporova i sukoba interesa unutar udruge.

69 Usp. Barbić, J., Pravo društava, Opći dio, Organizator, Zagreb, 2006., str. 158.

70 O tome detaljnije vidi Ploh, M., ,Ograničenja i mogućnosti financiranja malih i srednjih poduzeća u Republici Hrvatskoj“; Financije i pravo, br. 1, 2017., str. 79. i dalje.

71 Usp. Madl, R., Der Sportverein als Unternehmen: gesellschafts- und steuerrechtliche Gesichtspunkte, Wiesbaden, Gabler, 1994., str. 148. 
prema društvu je presumirana. Zato oni odgovaraju podjednako za radnje i posljedice odluka koje je uprava provodila, kao i za eventualne štete zbog propusta da poduzmu odgovarajuće mjere u interesu društva ili njegovih vjerovnika. Međutim, u slučaju opoziva imenovanja zbog važnog razloga, dakle, poslovno ili osobno uvjetovanog raskida ugovora, kao i u slučajevima isticanja zahtjeva za naknadu štete, teret dokazivanja konkretne odgovornosti jest na strani ovlaštenih organa društva. Tako se osigurava kontinuitet rada uprave, koja za razliku od udruge ne ovisi o tome kakav je stav na skupštini udruge zauzela većina članova udruge. Kod višečlane uprave, za odluke koje se donose skupno svi njezini članovi u pravilu odgovaraju solidarno i neograničeno. Pojedini član uprave, koji se ne slaže s nekom konkretnom odlukom, ima pravo i dužnost službeno, u formi zapisnički konstatiranog izdvojenog mišljenja, upozoriti na razloge osobnog profesionalnog distanciranja od dotične odluke. Ako većina članova uprave ipak usvoji takvu odluku, onda je član koji se ogradio dužan istu lojalno provoditi, jer sam čin izdvojenog mišljenja ne može ga ekskulpirati od sudjelovanja u odgovornosti kao člana uprave. ${ }^{72}$ Mora postojati i protuteža širokim ovlastima uprave. Uprava vodi poslove s pozornošću savjesnog gospodarstvenika. Riječ je o razmjerno strogoj osobnoj odgovornosti pa je time smanjena mogućnost da se te funkcije prihvati osoba koja nema potrebna znanja i vještine. ${ }^{73} \mathrm{Na}$ kraju se može zaključiti da je profesionalna uprava jamstvo višeg standarda kvalitete upravljanja društvom. Ovlasti skupštine i uprave strogo su razdvojene; dioničari organizirani na glavnoj skupštini mogu samo neizravno utjecati na sastav uprave i njenu poslovnu politiku odabirom članova nadzornog odbora. Jasno je uređena podjela ovlasti između organa tog društva ili uprave, nadzornog odbora i glavne skupštine (odnosno upravnog odbora i glavne skupštine u slučaju monističkog ustroja društva). Imajući u vidu trenutno stanje razvoja e-sporta kod nas, čini se da čak i u slučaju da njegovi natjecateljski dionici postanu subjekti sportskog prava, osnivanje e-sport kluba u pravnom obliku sportskog dioničkog društva za sudjelovanje u natjecanjima neće biti često u praksi.

\section{ZAKLJUČAK}

U radu se pokazalo da je e-sport ponajprije ozbiljan gospodarski pothvat kojim dominiraju izdavači video i računalnih igara korištenih u svrhu platforme za natjecanje. E-sport je izrastao iz supkulture i postao samostalni i samoodrživi ekosustav u kojem sudjeluju gospodarski i tržišno moćni igrači. Kod e-sporta ne postoji čvrsta organizacijska struktura koja bi odgovarala ustrojbenoj i hijerarhijskoj strukturi kakva postoji kod klasičnih sportova. Slobode digitalnog svijeta omogućuju e-sportašima da se natječu a da ne formiraju piramidalne strukture s krovnim

72 Uz to, uprava ima mandat u trajanju 5 godina, a može je se opozvati samo iz važnog razloga kao što je gruba povreda dužnosti, nesposobnost za obnašanje funkcije člana uprave ili ako glavna skupština izglasa nepovjerenje upravi. Detaljnije Čolaković, E., Menadžerski ugovori, CROMA, Zagreb, 2009., str. 35 .

73 Usp. Barbić, J., Pravo društava, Dioničko društvo, Organizator, Zagreb, 2010., str. 790. i dalje. 
sportskim savezom na čelu. Izdavači su nerijetko istovremeno i organizatori tih natjecanja, a natjecatelji su organizirani u tzv. klanovima. Spomenuti trgovci organiziranjem natjecanja populariziraju svoj proizvod pa time povećavaju svoju dobit od prodaje igara i druge robe koja je povezana s računalnom igrom. Uz njih, kao dionici u pothvatu e-sporta pojavljuju se sponzori, ulagači, marketinški sektor, organizatori igara na sreću te gledatelji. Različito od „klasičnih“ sportova kod kojih nema zaštite autorskih prava u smislu da je netko osmislio sport i njegova pravila, kod e-sporta zaštićen je kompjutorski program (programski kod) koji je temelj videoigre. Spomenuti sustav razvija se i bez ,titule“"sporta, pa je pravo pitanje koje bi prednosti i nedostatke priznanje e-sporta donijelo njegovim ključnim dionicima. Prednosti koje donosi priznanje e-sporta jesu njegovo šire društveno prihvaćanje što utječe i na popularnost, bolji pristup javnim izvorima financiranja, lakše ishođenje viza i boravišnih dozvola za e-sportaše, veća pravna sigurnost te brži globalni razvoj temeljem suradnje s drugim sportskim organizacijama. S druge strane, podvrgavanje e-sporta režimu sportskog prava ima i nedostatke jer se tada na e-sport natjecatelje primjenjuju npr. pravila o zabrani dopinga, zaštiti maloljetnika i sl. Statut i ostali opći akti Hrvatskog olimpijskog odbora dostatno su fleksibilni i nisu nepremostiva prepreka da nacionalna krovna udruga za e-sport postane članicom HOO-a, ali ključnu ulogu u tom procesu imat će Međunarodni olimpijski odbor koji šalje signale da se e-sport (barem kroz elektroničke sportske simulacije) približava uvjetima koje neka ljudska aktivnost mora ispuniti da bi je smatrali sportom. Kada se e-sportu prizna status sporta, tada njegovi dionici postaju subjektima sportskog prava. U svezi s pravnim ustrojem sportskih klubova kod nas, proizlazi da cee e-sport klubovi moći birati između dva pravna oblika: sportske udruge i sportskog dioničkog društva. Uzevši u obzir trenutno stanje, može se zaključiti da će sportske udruge zbog svih opisanih značajki u pravilu biti prvi izbor.

\section{LITERATURA}

1. Bagger von Grafenstein,T.; Bischoff, D., „Schaffung von e-Sport-strukturen in Verein“, Zeitschrift für Sport und Recht (SpuRt), br. 2., 2020, str. 75-79.

2. Bagger von Grafenstein, T., ,e-sport: Welche Vor- und Nachteile bringt eine rechtliche Qualifizierung als Sport mit sich?", Herausforderungen für die weitere Entwicklung des e-sport, Multimedia und Recht-Beilage (MMR - Beilage), br. 8, 2018., str. 20-24.

3. Barbić, J., Pravo društava, Dioničko društvo, Organizator, Zagreb, 2010.

4. Barbić, J., Pravo društava, Opći dio, Organizator, Zagreb, 2006.

5. Brtka, R., „e-sport: Die Spiele beginnen - Welche Rechtsfragen sind zu klären?“, Gewerblicher Rechtsschutz und Urheberrecht, Praxis im Immaterialgüter und Wettbewerbsrecht (GRUR-Prax), br. 22, 2017., str. 500-502.

6. Čolaković, E., Menadžerski ugovori, CROMA, Zagreb, 2009.

7. Frey, D.; Pommer, J., „Herausforderungen für die weitere Entwicklung des e-sport“, Multimedia und Recht-Beilage (MMR - Beilage), br. 8, 2018., str. 7-12. 
8. Hentsch, H. C., „Die Urheberrechte der Publisher bei e-sport“, Multimedia und RechtBeilage (MMR - Beilage), br. 8, 2018., str. 3-7.

9. Holzhäuser, F.; Bagger von Grafenstein, T.; Schenk, M., „Ist e-Sport „echte“ Sport?“, Zeitschrift für Sport und Recht (SpuRt), br. 3, 2016., str. 94-98.

10. Jagnow H.; Baumann A., „e-sport aus verbandlicher Perspektive“, Multimedia und Recht-Beilage (MMR - Beilage), br. 8, 2018., str. 12-16.

11. Kubiciel, M., „Entwicklung des e-sports und Schutz seiner Integrität“, Zeitschrift für Rechtspolitik, br. 7, ZRP, 2019., str. 865-870.

12. Kunda, I.; Matanovac Vučković R., „Raspolaganje autorskim pravom na računalnom programu - materijalnopravni i kolizijskopravni aspekti“, Zbornik Pravnog fakulteta Sveučilišta u Rijeci, br. 1, 2010., str. 85-131.

13. Madl, R., Der Sportverein als Unternehmen: gesellschafts- und steuerrechtliche Gesichtspunkte, Wiesbaden, Gabler, 1994.

14. Milanović/Čustonja/Bilić (Ur.), Temeljna načela i smjernice razvoja športa $u$ RH, Nacionalno vijeće za sport, Zagreb, 2011.

15. Pajčić, M; Sokanović, L., „Manipulacija rezultatima sportskih natjecanja“, Zbornik radova Pravnog fakulteta u Splitu, br. 4, 2011., str. 857-873.

16. Ploh, M., „Ograničenja i mogućnosti financiranja malih i srednjih poduzeća u Republici Hrvatskoj“, Financije i pravo, br. 1, 2017., str. 79-106.

17. Schmidt, K., „Gesellschaftsrecht“, 4. Auflage, Heymanns, München, 2002.

18. Schmidt, K., Verbandszweck und Rechtsfähigkeit im Vereinsrecht, Eine Studie über Erwerb und Verlust der Rechtsfähigkeit nichtwirtschaftlicher und wirtschaftlicher Vereine, Decker, Heidelberg, 1984.

19. Stöber, K., „Handbuch zum Vereinsrecht“, 8. Auflage, Köln, 2000.

20. Thorhauer, Y.; Jakob, A.; Ratz, M., „E-Sport - Skizze eines neuen Forschungsfeldes“, u: Thorhauer /Kexel (Ur.), Compliance im Sport - Theorie und Praxis, Springer Gabler, Wiesbaden, 2018. 


\section{E-SPORT AND THE QUESTION OF THE (FUTURE) LEGAL STRUCTURE OF E-SPORT CLUBS}

The paper proves that e-sports is primarily a serious economic venture dominated by publishers of video and computer games used as a platform for competition. E-sport has grown out of a subculture and has become an independent and self-sustaining ecosystem in which economically and market-powerful players participate. In e-sports, there is no organizational structure that would correspond to the organizational and hierarchical structure that exists in classic sports. The freedoms of the digital world allow e-athletes to compete without forming a pyramid structure with an umbrella sports federation at the helm. Publishers are often at the same time the organizers of these competitions and the competitors are organized in the so-called clans. By organizing competitions, the publishers popularize their product and thus increase their profit from the sale of games and other goods related to computer games. Along with them, sponsors, investors, the marketing sector, organizers of games of chance and spectators appear as stakeholders in the e-sports venture. Unlike "classic" sports in which there is no copyright protection in the sense that someone designed the sport and its rules, in e-sports a computer program (program code) is protected, which is the basis of a video game. The mentioned system is developing even without the "title" of sport, so the real question is what advantages and disadvantages the recognition of e-sport would bring to its key stakeholders. The advantages of e-sports recognition are its wider social acceptance, which also affects its popularity, better access to public funding, easier obtaining of visas and residence permits for e-sportsmen, greater legal security and faster global development through cooperation with other sports organizations. On the other hand, subjecting e-sports to the regime of sports law has its challenges because then the rules on doping, protection of minors and integrity of sports are applied to e-sports stakeholders. The Statute and other autonomous acts of the Croatian Olympic Committee are flexible enough for the national umbrella association for e-sports to become its member, but a key role in this process will be played by the International Olympic Committee, which sends signals that e-sports (at least through electronic sports simulations) is getting close of fulfilling the conditions required for any human activity to be recognized as sport. When e-sports are granted the status of a sport then its stakeholders shall become subjects of sports law. In connection with the legal structure of sports clubs in our country, it follows that e-sports clubs will be able to choose between two legal forms: sports associations and sports joint stock companies. Taking into account the current situation, it can be concluded that sports associations, as a rule, will be the first choice due to all its features described in this paper.

Key words: e-sport, sports association, sports joint stock company, Croatian Olympic Committee, organizer 